\title{
REMOVAL OF HYDROCARBONS FROM DRILL CUTTINGS USING HUMIC ACIDS IN WASHING PROCESSES
}

\author{
Remoción de hidrocarburos en recortes de perforación utilizando ácidos húmicos en procesos de lavado
}

\author{
Marcos Leopoldo INTERIANO LÓPEZ1 ${ }^{1}$ Víctor Ángel RAMÍREZ COUTIÑO², \\ Evelyn ZAMUDIO PÉREZ ${ }^{1}$, Luis A. GODÍNEZ ${ }^{1}$ and
} Francisco J. RODRÍGUEZ-VALADEZ ${ }^{1 *}$

\author{
${ }^{1}$ Centro de Investigación y Desarrollo Tecnológico en Electroquímica SC. Parque Tecnológico Querétaro \\ Sanfandila, Pedro Escobedo, Santiago de Querétaro, México CP. 76703 \\ ${ }^{2}$ Universidad Tecnológica de México, UNITEC-México, Campus Querétaro, Av. 5 de Febrero No. 1412, San \\ Pablo, 76130 Santiago de Querétaro, Querétaro, México \\ *Autor para correspondencia: frodriguez@cideteq.mx
}

(Received June 2018; accepted October 2018)

Key words: TPH, surfactants, humic acids, washing process

\begin{abstract}
In petroleum exploration drilling cuttings are generated, which are toxic residues that contain significant amounts of oil. The oil levels within the cuttings are a risk for marine and terrestrial environments. This study was carried out to investigate the removal of total petroleum hydrocarbons (TPH) in perforation cuttings (OBDC) by a washing process in which humic acids (HA) were used as surfactants. The cuttings contained $114372 \mathrm{mg} / \mathrm{kg}$ of TPH, which were washed with HA solutions, resulting in $80 \%$ removal of OBDC contaminants, applying a washing an additional water rinse. The process effectiveness was found strongly dependent on the HA solution concentration, the highest removal rates were attained using solutions in the range of 2500 to $3000 \mathrm{mg} / \mathrm{L}$, and lower concentrations yielded removal rates lower than $70 \%$. Comparing the use of HA versus synthetic surfactants, such as sodium dodecyl sulfate (SDS) and tween-20 (TW20), both resulted in lower removal efficiency than HA. An additional advantage of $\mathrm{HA}$ is that it is a natural material, therefore there is no risk of toxic side effects that occur with synthetic surfactants.
\end{abstract}

Palabras clave: TPH, surfactantes, ácidos húmicos, proceso de lavado

\section{RESUMEN}

En la exploración petrolera se generan recortes de perforación, los cuales son residuos tóxicos que contienen cantidades significativas de aceites. Los niveles de aceite en los recortes representan un riesgo para los ambientes marinos y terrestres. Este estudio se llevó a cabo para investigar la remoción de hidrocarburos totales de petróleo (TPH) en recortes de perforación (OBDC) mediante un proceso de lavado en el que se utilizaron ácidos húmicos (HA) como tensoactivos. Los recortes contenían inicialmente $114372 \mathrm{mg} / \mathrm{kg}$ de TPH, los cuales fueron lavados con soluciones de HA, obteniéndose una remoción del $80 \%$ utilizando un proceso de lavado y posterior enjuague con 
agua. Los resultados indican que la eficiencia del proceso depende de la concentración del HA, las mayores tasas de remoción se alcanzaron usando soluciones de 2500 a $3000 \mathrm{mg} / \mathrm{L}$ y concentraciones más bajas dieron tasas de eliminación menores del $70 \%$. Comparando el uso de tensoactivos sintéticos, tales como dodecilsulfato de sodio (SDS) y tween-20 (TW20), ambos resultaron con menor eficiencia que los HA. Una ventaja adicional de los HA es que son materiales presentes de manera natural en el ambiente para el que no se han identificado efectos secundarios tóxicos como sucede con los tensoactivos sintéticos.

\section{INTRODUCTION}

Oil-drilling wells generate large volumes of a byproduct known as "cuttings", which present a waste management problem for the petroleum industry (Al-Ansari and Al-Tabbaa 2007, Kogbara et al. 2016). This type of residue is generated when applying drilling fluids which act as a lubricant and coolant during the drilling process. Usually, the drilling cutting is a mixture of clay, quartz, feldspars, carbonates, and other calcareous compounds impregnated with hydrocarbons (Rojas-Avelizapa et al. 2007, Robinson et al. 2009, Bakke et al. 2013). Specifically, the cuttings contain highly toxic and poorly biodegradable contaminants, such as aliphatic hydrocarbons, polycyclic aromatic hydrocarbons (PAHs), and polychlorinated biphenyls (PCBs), as well as heavy metals, such as Pb, Ba, Zn, Hg, Cr, As, and Ni (Neff 2005, Leonard and Stegemann 2010, Junior et al. 2015). This residue represents a high environmental risk; therefore, alternatives for its management and treatment must be found to minimize the environmental threats and negative side effects on the population. Currently, the alternatives that are available for management of cuttings are reuse/recycling, sludge re-injection, and component separation by means of vibrating screens, hydrocyclones, and centrifugal decanters (Njobuenwu and Wobo 2007, Mognonda et al. 2015). Additionally, efforts have been made to treat the cuttings by several techniques such as solidification/stabilization, thermal and microwave treatment, supercritical fluid extraction, and washing processes using synthetic surfactants (Carignan et al. 2007, Robinson et al. 2010, Yan et al. 2011, Ball et al. 2012, Khanpour et al. 2014). This last method is a physicochemical technique that has received special interest because it is relatively fast and has a moderate impact on processing costs because it can be used to treat large volumes of waste (Urum et al. 2006, Han et al. 2009). However, the use of synthetic surfactants can itself be a source of environmental problems due to their toxicity and low biodegradability.
The reported toxicity of surfactants on soil microbial cells indicates that they can seriously affect the biodegradation capability of microorganisms and the balance of biological activity (Sandbacka et al. 2000). In washed drill cuttings, the use of natural surfactants is an attractive alternative that appears to be a viable replacement for synthetic surfactants (Perminova and Hatfield 2005, Zacarias et al. 2013). Natural surfactants are molecules that can effectively reduce water surface tension, exhibit excellent surface activity, and display better compatibility with the environment since they are nontoxic and biodegradable (Klavins and Purmalis 2010). One of the most promising natural surfactants are the humic acids (HA), a naturally occurring organic component of soil, water, and sediments. HA are largely composed of aromatic rings and aliphatic structures linked to other structures and have an aliphatic character (Barak and Chen 1992, Liang et al. 2006) because they are a byproduct of organic matter degradation (Ramírez et al. 2013a). In a previous work, Conte et al. (2005) evaluated hydrocarbon removal in highly contaminated soil by washing processes with different synthetic surfactants and HA, experiments were conducted using two polluted soils and solutions of either synthetic or natural surfactants (HA). Their results demonstrated that HA were able to reduce the level of TPH contaminants between 80 to $90 \%$, which was the first time a natural nontoxic surfactant such as HA was reported to have a similar capacity for removing contaminants from polluted soil as that exhibit by synthetic surfactants. The effectiveness of $\mathrm{HA}$ in the washing process may be related to the fact that this compound acts on soil particle surfaces, also it has a high capacity to solubilize a wide variety of hydrophobic species and to develop micellar structures similar to those of synthetic surfactants (Wandruszka 2000).

At the present time, no studies on the application of HA as a surfactant in treating drill cuttings have been reported. Therefore, the aim of this study is to evaluate the use of humic acids as a surfactant for 
removing hydrocarbons contained in drill cuttings and to compare their efficiency with known synthetic surfactants such as sodium dodecyl sulfate (SDS) and tween-20 (TW20).

\section{MATERIALS AND METHODS}

\section{Materials}

The surfactants SDS and TW20 used in the experiments were obtained from Sigma-Aldrich. Their chemical properties are given as follow. SDS anionic surfactant: hydrophilic-lipophilic balance (HLB) 40, molecular weight $288.37 \mathrm{~g} / \mathrm{mol}$, critical micelle concentration (CMC) $2880 \mathrm{mg} / \mathrm{L}$; TW20 non-ionic surfactant: HLB 16.7, molecular weight $1228 \mathrm{~g} / \mathrm{mol}$, density $1.095 \mathrm{~g} / \mathrm{mL}$, critical micelle concentration (CMC) $60 \mathrm{mg} / \mathrm{L}$.

The humic acids (HA) were obtained from compost produced by mixing $30 \%$ municipal sewage sludge, $60 \%$ grass and $10 \%$ wooden shavings, its CMC is $2000 \mathrm{mg} / \mathrm{L}$ (Ramírez et al. 2013b).

The oil-based drill cuttings (OBDC) used in the experiments were obtained from an installation located in the State of Veracruz, Mexico. TPH concentration in OBDC samples were $114372 \mathrm{mg} / \mathrm{kg}$.

\section{Washing process with HA solutions}

To evaluate the effect of humic acids on the removal of hydrocarbons contained in the OBDC, a $100 \mathrm{~g}$ sample was placed in a glass container to which $500 \mathrm{~mL}$ of a humic acid solution $(2000 \mathrm{mg} / \mathrm{L})$ was added. The container was collocated in a jar test

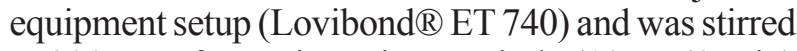
at $200 \mathrm{rpm}$ for various time periods (10 to $60 \mathrm{~min}$ ) then left to rest for $30 \mathrm{~min}$. Afterward, the washing solution was separated by decanting and the settled solid was dried at room temperature for three days.

The treated OBDC was milled in a porcelain mortar and sieved through a $0.5 \mathrm{~mm}$ mesh to obtain a homogenous particle size. Later, the TPH content was determined by Soxhlet extraction and this value was compared with the initial concentration to determine the rate of removal in the sample.

\section{Washing process with HA solutions and rinsing with water \\ As a complement to the HA washing process, an additional rinsing step with water was evalu- ated, with the objective of identifying any potential further increase in TPH removal efficiency. In this case, the OBDC sample was treated as described in previous section and after separation from the humic}

acid solution, the settled solid was kept in a glass container. Later, $500 \mathrm{~mL}$ of distilled water was then added, and the sample was again placed in the jar test equipment setup where it was stirred for $30 \mathrm{~min}$ at $200 \mathrm{rpm}$. Afterward, the TPH concentration in the solid was determined.

\section{TPH removal at different HA concentrations}

To determine whether the washing efficiency was influenced by HA concentrations in the washing solutions, concentrations between 500 to $3000 \mathrm{mg} / \mathrm{L}$ were prepared with distilled water. The washing experiments were performed according to the procedures and conditions reported in section washing process with HA solutions and rinsing, with an applied washing time between 10 to $60 \mathrm{~min}$.

\section{Comparison between washing with $\mathrm{HA}$ and synthetic surfactants}

In order to compare the effectiveness of the elimination of TPH with HA and synthetic surfactants, each of these substances were prepared to CMC. This is the concentration at which surfactants are known to form structures known as micelles which have been reported to play an important role in solubilizing compounds. The CMC prepared solutions were: HA $(2000 \mathrm{mg} / \mathrm{L}), \operatorname{SDS}(2880 \mathrm{mg} / \mathrm{L})$, and TW20 $(60 \mathrm{mg} / \mathrm{L})$.

The OBDC applied treatment, TPH extraction and quantification were performed according to the procedures previously described, applying washing time of $30 \mathrm{~min}$.

\section{Soxhlet extraction}

To determine TPH concentration, the standard EPA 9071B and EPA1664A (1998) methodologies were used.

\section{Organic matter content}

The organic matter contained in the samples was determined by titration with the Walkley-Black method (Gelman et al. 2012).

\section{RESULTS AND DISCUSSION}

\section{Removal of TPH in OBDC, washing with HA solutions and rinsing}

Recent studies have reported that when a soil is contaminated, hydrocarbons tend to move into the deeper recesses of soil particles, soil aggregates and the organic matter adsorbed to soil particle surfaces (Prichard et al. 2006, Bezza and Nkhalambayausi 
2015). As a result, in the washing process, desorption is commonly considered as a rapid initial release of hydrocarbons that are close to the surface and a very slow release of hydrocarbons that are more deeply adsorbed. For this reason, the fastest and highest removal was carried out in the first $30 \mathrm{~min}$ and a slower removal was observed after this time.

In figure 1, the washing experiment results indicate that the HA solutions were able of remove TPH from the solid matrix, with nearly $25 \%$ of TPH in the first $30 \mathrm{~min}$; when the washing times were 40 to $60 \mathrm{~min}$ the removal increased to about $30 \%$. On the other hand, when the samples were rinsed with water after washing, the TPH removal increased near $60 \%$ in the first 30 minutes that is three times greater than the washing with HA.

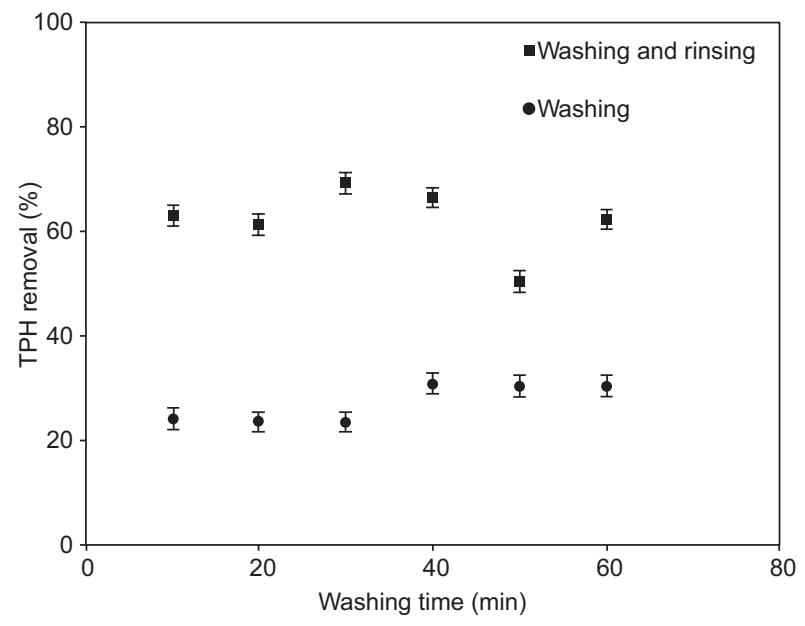

Fig. 1. Removal of total petroleum hydrocarbons (TPH) in perforation cuttings (OBDC) samples using as washing solution $2000 \mathrm{mg} / \mathrm{L}$ humic acids (HA) with rinsing and without rinsing

This effect can be explained by the interaction of HA with the OBDC sample, since when the surfactant molecules are present in a heterogeneous soil-water system, they could adsorb on the surface of the soil particles, giving rise to interactions between the hydrophilic groups (or head groups) that enter the aqueous phase and lipophilic groups (or tail groups) that tend to combine with hydrophobic contaminants and with soil particles that reduce the elimination of TPH (Mulligan et al. 2001, Vishnyakov et al. 2013). However, when the rinse is carried out, desorption of HA with the contaminant in the OBDC is facilitated resulting in increased removal.

The results obtained were similar to those reported by Conte et al. (2005) that show rates of hydrocarbon removal between $70 \%$ and $80 \%$ in soil samples with a wash without rinse. However, they used a wash time of $24 \mathrm{~h}$ which could facilitate the removal due to a longer contact time between the HA solution and the pollutants. So, it can be noted that the rinse after washing decreases the time of TPH removal which is more convenient for the treatment of these pollutants.

\section{TPH removal as a function of $\mathrm{HA}$ concentration in continuous washing processes}

The removal rates of TPH in OBDC samples using $\mathrm{HA}$ at various concentrations above and below the CMC are shown in figure $2 \mathbf{A}$ and $\mathbf{B}$. The contaminants were mostly removed in the first 10 min of contact, demonstrating that the washing time is not important in the removal of TPH with respect to the $\mathrm{AH}$ concentration, so there is no need to use longer treatment times.

As can be seen, water alone removes $17 \%$ of the contaminants in the sample, this can be explained by the high hydrophobicity of hydrocarbons. When 500, 1000 and $1500 \mathrm{mg} / \mathrm{L} \mathrm{HA}$ solutions were used in the
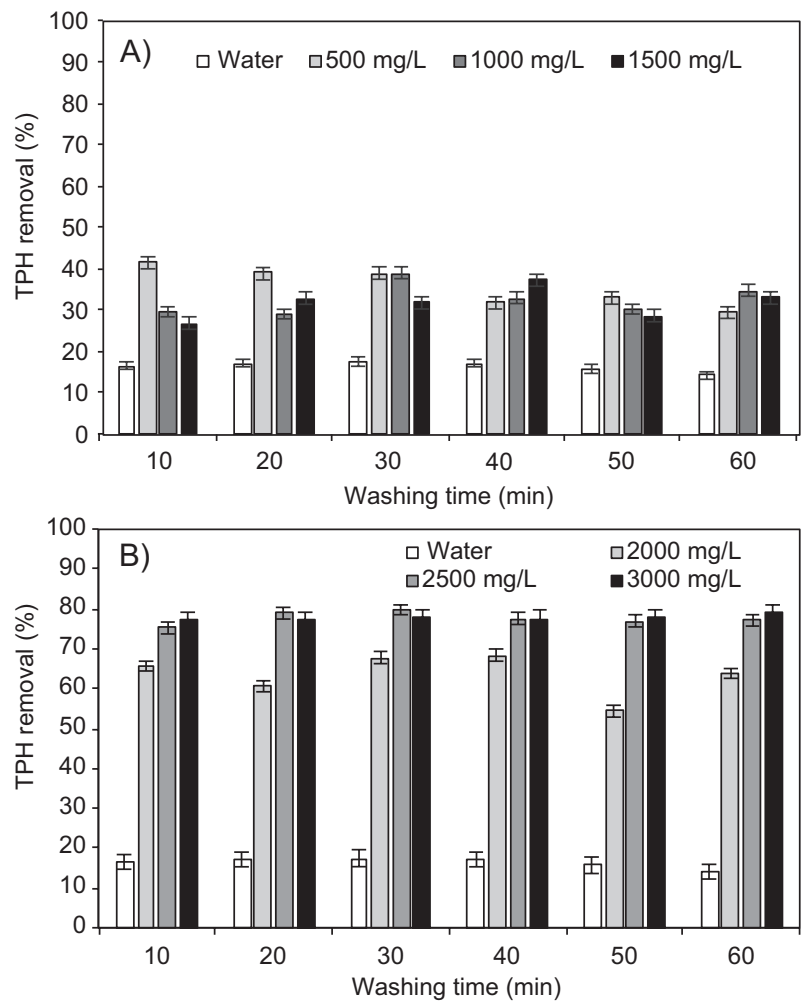

Fig. 2. A) Removal of total petroleum hydrocarbons (TPH) in washing with different humic acids (HA) concentrations below the critical micelle concentration (CMC), B) Removal of TPH in washing with $\mathrm{HA}$ at the $\mathrm{CMC}$ and above 
washing process, the removal rate increases to values between $30 \%$ and $40 \%$. It is worth noting that the highest removal rate was attained at a concentration of $500 \mathrm{mg} / \mathrm{L} \mathrm{HA}$ and $10 \mathrm{~min}$ of washing.

The phenomena associated with this result have been explained in studies showing that when surfactants are added into the water-soil system, a certain amount of surfactants will inevitably be adsorbed by soil particles (Paria 2008, Mao et al. 2015). The more the adsorbed surfactants, the less the surfactants contribute to the mobilization of pollutants. Moreover, the hydrophobicity of the soil is increased as the surfactants adsorbed onto soil particles. As a result, removed TPH will be re-adsorbed on soil surface, in such a way that when washing was carried out at concentrations 1000 and $1500 \mathrm{mg} / \mathrm{L}$, re-adsorption of HA-TPH could have occurred in the soil, resulting in lower removal percentages than those obtained in washes at concentrations of $500 \mathrm{mg} / \mathrm{L}$.

When using concentrations equal to or above $\mathrm{CMC}$, the process becomes more efficient, as demonstrated by the significant increase in removal rate (Fig. 2 B). In this case, at 10 min the removal percentages reached values between 66 and $78 \%$, with an HA concentration of $3000 \mathrm{mg} / \mathrm{L}$ yielding the best results. For longer contact times, the removal rate remained near $80 \%$ using HA solutions of 2500 and $3000 \mathrm{mg} / \mathrm{L}$. Otherwise, solutions at the CMC of 2000 $\mathrm{mg} / \mathrm{L}$ always displayed efficiencies lower than $70 \%$. The increase in organic pollutant removal agrees well with the results obtained by Pan et al. (2006) for the solubilization of hydrophobic organic contaminants using a series of HA from different sources. The increase in the removal of TPH where the concentration was between 2000 and $2500 \mathrm{mg} / \mathrm{L}$ is related with the formation of the pseudomicelles of the humic acids. So, when the CMC is $2000 \mathrm{mg} / \mathrm{L}$, the pseudomicelles could be wrapping the contaminants. According to the obtained results, there is a high removal in the concentration above $2000 \mathrm{mg} / \mathrm{L}$, but there is no significant difference when using 2500 and $3000 \mathrm{mg} / \mathrm{L}$.

As can be seen (Fig. 2 A and B) the highest removal of TPH was obtained with solutions above the CMC of HA. The obtained results are similar to studies carried out on the application of surfactants to improve ex situ soil washing (Urum et al. 2003, Muherei and Junin 2007, Pacwa et al. 2011). These studies have proposed two hydrocarbon removal mechanisms using surfactant solutions: mobilization and solubilization. The mobilization mechanism occurs at concentrations below the $\mathrm{CMC}$, and it is associated to reduction of surface and interfacial tension, reduction of capillary force, wettability and reduction of contact angle. In turn, above the surfactant CMC, the solubilization takes place when these molecules are incorporated into a micelle, resulting in highest removal of TPH when surfactant solutions are used above the CMC.

\section{Determination of $\mathrm{OM}$ in washing/rinsing cuttings samples with HA}

Figure 3 displays the organic matter content of the samples after washing and rinsing. The original organic matter content in the sample was $6.4 \%$ and decreased to $5.8 \%$ when the sample was washed only with water. When the concentration of HA in the solutions is increased, the OM content in the cuttings decreases so that the organic matter contents were $5.2 \%, 2.2 \%$, and $2.8 \%$ with HA concentrations of $500 \mathrm{mg} / \mathrm{L}, 2500 \mathrm{mg} / \mathrm{L}$, and $3000 \mathrm{mg} / \mathrm{L}$, respectively.

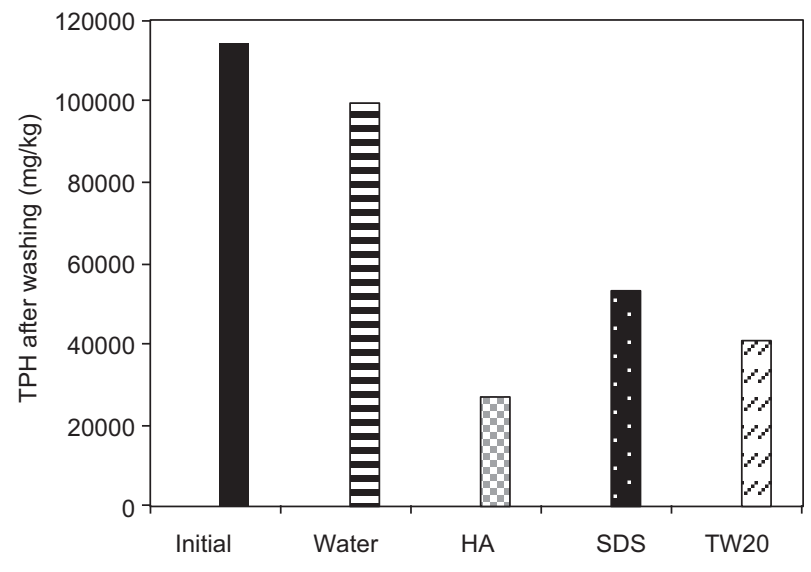

Fig. 3. Percentage of organic matter in cuttings after washing and rinsing with water and different HA concentrations

Fluctuations in the percentage of OM content have a similar trend to the removal of TPH by washing/ rinsing using similar concentrations of HA. When HA solutions are used in concentrations higher than $\mathrm{CMC}$ the percentage of $\mathrm{OM}$ that remained in the sample decreased, indicating that the HA desorb the OM contained in the cuttings. According to this, there is some evidence that most of the organic matter contained in the cuttings are related with the content of hydrocarbons.

The low content of organic matter $(6.2 \%)$ compared to the high concentration of TPH in the sample (114372 mg/kg) could be explained by the fact that the determination of the Walkley-Black method has a limitation, which is that it can only quantify organic matter easily oxidizable by potassium dichromate, Hence, the value obtained is lower than the actual total organic content (TOC), 
so that the TOC value could be 1.23 to 1.58 higher than the oxidizable organic carbon (De Vos 2007). Then, the total organic carbon in the OBDC sample is greater than $6.2 \%$.

\section{Comparison of washing using $\mathrm{HA}$ and synthetic surfactants at CMC}

The results of washing experiments on OBDC samples using either synthetic surfactants or HA solutions are shown in figure 4. It is clear that all of the surfactants removed the contaminants contained in the sample, although the HA solution displayed the best performance reaching a decrease in TPH concentration in the OBDC sample from 114372 to $34216 \mathrm{mg} / \mathrm{kg}$ (70 \% removal). Among the synthetic surfactants, TW20 performed best as indicated by a reduction in TPH concentration to $52513 \mathrm{mg} / \mathrm{kg}$, while SDS reduced the hydrocarbon content to $80000 \mathrm{mg} / \mathrm{kg}$ of TPH in the sample.

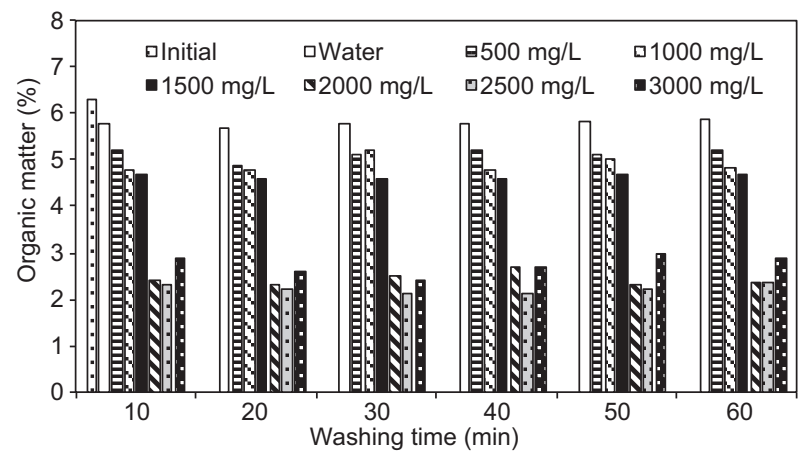

Fig. 4. Removal of total petroleum hydrocarbons (TPH) using synthetic surfactants and a humic acid (HA) solution at the critical micelle concentration (CMC)

The experimental results indicate that under CMC conditions the HA remove efficiently the TPH contained in cuttings, obtaining better results than synthetic surfactants.

Conte et al. (2005) obtained similar results of removal in washes with SDS, Triton-100 and HA, explaining that synthetic or natural surfactants in the washing techniques have the effect of increasing the structural stability of the soil due to the aggregating action that the hydrophobicity of the surfactants can exert on the solid particles of the soil, affecting the solubilization of contaminants. This may explain that the SDS and TW20 at CMC are more easily adsorbed to the OBDC particles, resulting in the HA being less adsorbed, having more micelles that can solubilize TPH by increasing the removal.

\section{CONCLUSIONS}

In the present study, HA solutions were used to perform washing processes of an OBDC sample containing $114372 \mathrm{mg} / \mathrm{kg}$ of TPH. The washing/rinsing treatment using HA concentration of $2500 \mathrm{mg} / \mathrm{L}$ removed $80 \%$ of the TPH in the cuttings. Removal percentage of TPH depends on the concentration of the HA solution, with the best results found for concentrations above the CMC. A comparison of the efficiency attained with HA solutions and synthetic surfactants indicates that the natural surfactant exhibits better performance, demonstrating its technical viability for use in washing drilling cuttings.

\section{ACKNOWLEDGMENTS}

Marcos Leopoldo Interiano López thanks CONACyT (Consejo Nacional de Ciencia y Tecnología) for a scholarship.

\section{REFERENCES}

Al-Ansary M.S. and Al-Tabbaa A. (2007). Stabilization/ solidification of synthetic petroleum drill cuttings. J. Hazard. Mater. 141 (2), 410-421.

DOI: 10.1016/j.jhazmat.2006.05.079

Bakke T., Klungsoyr J. and Sanni S. (2013). Environmental impacts of produced water and drilling waste discharges from the Norwegian offshore petroleum industry. Mar. Environ. Res. (92), 154-169. DOI: 10.1016/j.marenvres.2013.09.012

Ball A.S., Stewart R.J. and Schliephake K. (2012). A review of the current options for the treatment and safe disposal of drill cuttings. Waste Manage. Res. 30 (5), 457-473. DOI: 10.1177/0734242X11419892

Barak P. and Chen Y. (1992). Equivalent radii of humic macromolecules from acid-base titration. Soil Sci. 154 (3), 184-195.

DOI: 10.1097/00010694-199209000-00002

Bezza F.A and Nkhalambayausi-Chirwa E.M. (2015). Desorption kinetics of polycyclic aromatic hydrocarbons (PAHs) from contaminated soil and the effect of biosurfactant supplementation on the rapidly desorbing fractions. Biotechnol. Biotec. Eq. 29 (4), 680-688. DOI: $10.1080 / 13102818.2015 .1028444$

Carignan M.P., Lake C.B. and Menzies T. (2007). Assessment of two thermally treated drill mud wastes for landfill containment applications. Waste Manage. Res. 25 (5), 394-401. DOI: $10.1177 / 0734242 X 07073652$ 
Conte P., Agretto A., Spaccini R. and Piccolo A. (2005). Soil remediation: humic acids as natural surfactants in the washings of highly contaminated soils. Environ. Pollut. 135 (3), 515-522.

DOI: 10.1016/j.envpol.2004.10.006

De Vos B., Lettens S., Muys B. and Deckers J. A. (2007). Walkley-Black analysis of forest soil organic carbon: recovery, limitations and uncertainty. Soil use and Manage. 23 (3), 221-229.

DOI: $10.1111 / j .1475-2743.2007 .00084 . x$

Gelman F., Binstock R. and Halicz L. (2012). Application of the Walkley-Black titration for the organic carbon quantification in organic rich sedimentary rocks. Fuel (96), 608-610.

Han M., Ji G. and Ni J. (2009). Washing of field weathered crude oil contaminated soil with an environmentally compatible surfactant, alkyl polyglucoside. Chemosphere 76 (5), 579-586.

DOI: 10.1016/j.chemosphere.2009.05.003

Junior I.P., Pereira M.S., Santos J.M., Duarte C.R., Ataíde C.H. and Panisset C.M. de Á. (2015). Microwave remediation of oil well drill cuttings. J. Petrol. Sci. Eng. (134), 23-29. DOI: 10.1016/j.petrol.2015.07.022

Khanpour R., Sheikhi-Kouhsar M.R., Esmaeilzadeh F. and Mowla D. (2014). Removal of contaminants from polluted drilling mud using supercritical carbon dioxide extraction. J. Supercrit. Fluid. (88), 1-7.

DOI: $10.1016 /$ j.supflu.2014.01.004

Klavins M. and Purmalis O. (2010). Humic substances as surfactants. Environ. Chem. Lett. 8 (4), 349-354. DOI: $10.1007 / \mathrm{s} 10311-009-0232-\mathrm{z}$

Kogbara R.B., Ayotamuno J.M., Onomah I., Ehio V. and Damka, T.D. (2016). Stabilisation/solidification and bioaugmentation treatment of petroleum drill cuttings. Appl. Geochem. (71), 1-8

DOI: 10.1016/j.apgeochem.2016.05.010

Leonard S.A. and Stegemann J. (2010). Stabilization/ solidification of petroleum drill cuttings: Leaching studies. J. Hazard. Mater. 174 (1-3), 484-491.

DOI: 10.1016/j.jhazmat.2009.09.078

Liang C., Dang Z., Xiao B., Huang W. and Liu C. (2006). Equilibrium sorption of phenanthrene by soil humic acids. Chemosphere 63 (11), 1961-1968.

DOI: 10.1016/j.chemosphere.2005.09.065

Mao X., Jiang R., Xiao W. and Yu J. (2015). Use of surfactants for the remediation of contaminated soils: A review. J. Hazard. Mater. 285 (21), 419-435.

DOI: $10.1016 /$ j.jhazmat.2014.12.009

Mognon J.L., da Silva J.M., Bicalho I.C., Ataíde, C.H. and Duarte C.R. (2015). Modular mini-hydrocyclone desilter type of $30 \mathrm{~mm}$ : an experimental and optimization study. J. Petrol. Sci. Eng. (129), 145-152.

DOI: $10.1016 /$ j.petrol.2015.02.037
Muherei MA. and Junin R. (2007). Effect of electrolyte on synergism of anionic-nonionic surfactant mixture. J. Appl. Sci. (7), 1362-1371.

DOI: $10.3923 /$ jas.2007.1362.1371

Mulligan C.N., Yong R.N. and Gibbs B.F. (2001). Surfactant-enhanced remediation of contaminated soil. A review. Eng. Geol. 60 (1-4), 371-380.

DOI: $10.1016 / \mathrm{S} 0013-7952(00) 00117-4$

Neff J.M. (2005). Composition, environmental fates, and biological effects of water based drilling muds and cuttings discharged to the marine environment. Prepared for petroleum environmental research forum (PERF) and american petroleum institute [online]. http://www.perf.org/images/Archive_Drilling_Mud. pdf 30/08/2016

Njobuenwu D.O. and Wobo C.A. (2007). Effect of drilled solids on drilling rate and performance. J. Petrol. Sci. Eng. 55 (3-4), 271-276.

DOI: $10.1016 /$ j.petrol.2006.08.012

Pacwa-Plociniczak M., Płaza G.A., Piotrowska-Seget Z. and Cameotra S.S. (2011). Environmental applications of biosurfactants: recent advances. Int. J. Mol. Sci. 12 (1), 633-654. DOI: 10.3390/ijms12010633

Pan B., Xing B.S., Liu W.X., Tao S., Lin X.M., Zhang X.M., Zhang Y.X., Xiao Y., Dai H.C. and Yuan H.S. (2006). Distribution of sorbed phenanthrene and pyrene in different humic fractions of soils and importance of humin. Environ. Pollut. 143 (1), 24-33.

DOI: 10.1016/j.envpol.2005.11.009

Paria S. (2008). Surfactant-enhanced remediation of organic contaminated soil and water. Adv. Colloid Interfac. Sci. 138 (1), 24-58. DOI: 10.1016/j.cis.2007.11.001

Perminova I.V. and Hatfield K. (2005). Remediation chemistry of humic substances. Theory and implications for technology. Springer. Printed in the Netherlands. 3-36 p. DOI: $10.1007 / 1-4020-3252-8 \_1$

Prichard H., Jones-Meehan J., Nestler C., Hansen LD., Straube W., Jones W., Hind J. and Talley J. (2006). Polycyclic aromatic hydrocarbons (PAHs): improved land treatment with bioaugmentation. In: Bioremediation of recalcitrant compounds, Vol. 1 (J. Talley, Ed.). CRC Press, Boca Raton, Florida, EUA, pp. 215-300.

Ramírez-Coutiño V.A., Torres L.G., Godínez L.A., Guerra R.J. and Rodríguez F.J. (2013). pH Effect on surfactant properties and supramolecular structure of humic substances obtained from sludge composting. Rev. Int. Contam. Ambie. 29 (3), 191-199.

Ramírez-Coutiño V.A., Wrobel K., Navarro R., Godínez L.A., Teutli M. and Rodríguez F.J. (2013). Evaluation of the composting process in digested sewage sludge from a municipal wastewater treatment plant in the city of San Miguel de Allende, Central México. Rev. Int. Contam. Ambie. 29 (Sup. 3), 89-97. 
Robinson J.P., Kingman S.W., Snape C.E., Barranco R., Shang H., Bradley M.S.A. and Bradshaw, S.M. (2009). Remediation of oil-contaminated drill cuttings using continuous microwave heating. Chem. Eng. J. 152 (23), 458-463. DOI: 10.1016/j.cej.2009.05.008

Robinson J.P., Kingman S.W., Snape C.E., Bradshaw S.M., Bradley M.S.A., Shang H. and Barranco R. (2010). Scale-up and design of a continuous microwave treatment system for the processing of oil-contaminated drill cuttings. Chem. En. Res. Des. 88 (2), 146-154. DOI: 10.1016/j.cherd.2009.07.011

Rojas-Avelizapa N.G., Roldán T., Zegarra H., Muñoz A. and Fernández L., (2007). A field trial for an ex-situ bioremediation of a drilling mud-polluted site. Chemosphere 66 (9), 1595-1600.

DOI: 10.1016/j.chemosphere.2006.08.011

Sandbacka M., Christianson I. and Isomaa B. (2000). The acute toxicity of surfactants on fish cells, daphnia magna and fish-a comparative study. Toxicol. in Vitro 14 (1), 61-68. DOI: $10.1016 / \mathrm{S} 0887-2333(99) 00083-1$

Urum K., Grigson S., Pekdemir T. and McMenamy S. (2006). A comparison of the efficiency of different surfactants for removal of crude oil from contaminated soils. Chemosphere 62 (9), 1403-1410. DOI: 10.1016/j. chemosphere.2005.05.016
Urum K., Pekdemir T. and Gopur M. (2003). Optimum conditions for washing of crude oil-contaminated soil with biosurfactant solutions. Process Saf. Environ. 81 (3), 203-209. DOI: 10.1205/095758203765639906

Vishnyakov A., Lee M.T. and Neimark AV. (2013). Prediction of the critical micelle concentration of nonionic surfactants by dissipative particle dynamics simulations. J. Phys. Chem. Lett. 4 (5), 797-802.

DOI: $10.1021 / \mathrm{jz} 400066 \mathrm{k}$

Wandruszka V.R. (2000). Humic acids: Their detergent qualities and potential uses in pollution remediation. Geochem. T. (2), 1-10. DOI: 10.1186/1467-4866-1-10

Yan P., Lu M., Guan Y., Zhang W. and Zhang Z. (2011). Remediation of oil-based drill cuttings through a biosurfactant-based washing followed by a biodegradation treatment. Bioresour. Technol. 102 (22), 10252-10259. DOI: 10.1016/j.biortech.2011.08.074

Zacarias M., Vaca M., Flores M.A., Bandala E.R. and Torres L.G. (2013). Surfactant-enhanced washing of soils contaminated with wasted-automotive oils and the quality of the produced wastewater. J. Environ. Prot. 4 (12), 1495-1501. DOI: 10.4236/jep.2013.412171 